\title{
Can Universities be a Platform for Climate Mitigation? Exploring the Impacts of Carbon Pricing in the University Setting
}

Suyeon Lee ( $\sim$ lee.suyeon@snu.ac.kr)

Seoul National University

\section{Seyeon Lee}

Syracuse University

\section{Research}

Keywords: Higher Education Institutions, Carbon Pricing, Waste Management and Recycling, Climate Mitigation, and Sustainability

Posted Date: January 19th, 2021

DOI: https://doi.org/10.21203/rs.3.rs-148453/v1

License: (c) (i) This work is licensed under a Creative Commons Attribution 4.0 International License. Read Full License 


\section{Abstract}

Climate Change is one of the most important threats in the world today and it is driven by the human-induced build-up of greenhouse gases (GHG) in the atmosphere. Despite worldwide policy efforts from the Kyoto Protocol to the Paris Agreement, global emissions of GHG have continued to steadily increase over the past decade. Against this backdrop, many higher education institutions (HEls) around the world began to engage in sustainable practices implementing green initiatives on their campuses. Using the waste disposal and the associated GHG emissions data from the academic community, this study describes how HEls can assume a leadership role in climate mitigation through the implementation of a carbon pricing initiative. Specifically, this study estimates the economic costs of carbon emissions from waste and conceptualizes how revenues generated from carbon pricing can be rechanneled to support carbon reduction efforts in HEls. By this approach, HEls not only create incentives for campus users such as students and employees to choose cleaner options but also be able to understand their own carbon footprint and adjust strategy accordingly. While carbon pricing has long been regarded as an alternative approach to tackle carbon pollution, it has not been much discussed in the area of waste management. In this regard, this study attempted to fill this research gap by finding emission reduction potentials in waste management using carbon pricing as a mechanism.

\section{Introduction}

Greenhouse gas $(\mathrm{GHG})$ emissions are recognized as the main driver of global warming and climate change. While carbon dioxide (CO2), methane ( $\mathrm{CH} 4)$, nitrous oxide (N2O), and fluorinated gases are considered as the high global warming potential gases contributing to warming the earth, carbon dioxide (CO2) accounting for more than 80 percent of global GHG emissions are known to bring the worst impact to the atmosphere (1).

Starting with the Kyoto Protocol in 1997, a number of international treaties for limiting GHG emissions have been made over the past decades, and in 2015, the Paris Agreement - the first time legally binding international treaty on climate change, was signed, which built a new global momentum to tackle the climate crisis across the world. In tandem, progress has been made on almost every front, from bold corporates setting their emissionreduction targets to youth activists protesting against climate change. The academic community has also ramped up its efforts to implement environmental policies and put a brake on activities within university campuses that could facilitate global warming (2) Today more and more countries, regions, cities, companies, and schools are establishing carbon neutrality targets.

More than 36 billion metric tons of CO2 were emitted globally in 2019 alone. While there has been year-to-year variability, $\mathrm{CO} 2$ emissions have steadily increased for the past decades with China and the U.S. being the largest emitters in the world (3). While the energy sector is the largest contributor to $\mathrm{CO} 2$ emissions, a significant amount of the carbon footprint is originated from urban waste treatment systems, particularly at landfill disposal due to the GHG emissions resulting from the main activities of the landfill during degradation waste processes and the burning of fossil fuels in equipment machinery and so on $(3,4)$. The emission from landfill sites accounts for approximately $5 \%$ of the global GHG emissions (5-7).

Now, the Covid-19 pandemic is making the situation worse. While the global GHG emissions dropped by $7 \%$ amid COVID-19 due to lockdown and preventive measures around the globe (8-10), one of the fallouts of the pandemic is the sudden surge in the number and amount of COVID-19 wastes. Since the advent of COVID-19, 
the use of protective gears such as facial masks, gloves, disinfectant wipes, sanitizer bottles, and food packaging have become a norm creating added types of wastes (11-14). Millions of people around the globe are littering those 'COVID-19 items' every day. Disposable plastic items are reintroduced into lives back-dating our recycling efforts due to growing concerns of hygiene (15). It poses a new challenge to develop innovative solutions and policies to the added waste concerns, and yet, the volume of single-use products, panic buying packages grow across the globe.

\subsection{The United States being the Most Wasteful Country In the World}

While over two billion tonnes of municipal solid waste are produced every year, the worst offenders are the U.S. citizens producing three times the global average of waste $(16,17)$. While the U.S. accounts for only about four percent of the world's population, it generates 12 percent of the world's municipal solid waste. In comparison, China and India, making up more than 36 percent of the world's population, yet generate about 27 percent of the global waste. The average amount of waste Americans create per day is about 4.9 pounds whereas, in Europe, the average amount weighs in at 2.9 pounds $(4,18)$

When it comes to recycling, the U.S. again lags behind other countries. Despite EPA's recent release about an increase in the average recycling rates to around 32 percent in 2018, this rate is still significantly lower than the one of other leading countries like Germany where people recycle around 68 percent of materials $(7,16,17,19)$. This indicates that more than half of the wastes sent to landfills in the U.S. are recyclable items (see figure 1).

The U.S. is one of the very few developed countries that still ship its waste to other nations failing in recycling, composting, and combustion with energy recovering $(16,17)$. For years, the U.S. sold millions of tons of trash to China but in 2018, China banned the import of foreign waste as a gesture of cleaning its environment. Yet, the U.S. is still trading more than one million tons a year of its plastic waste to developing nations including Cambodia, Laos, Ghana, Ethiopia, Kenya, and Senegal (16). This has contaminated and polluted the land and sea of those importing nations, and now the population of these nations faces a growing burden from new environmental risks to air, water, land, and health (20). In fact, the environmental costs are now greater than the income they bring in from importing the waste. It is only a matter of time before these waste importers take the same path as China and demand the U.S. to deal with its waste problem.

\subsection{Waste in Higher Education Institutions (HEls)}

The average college student produces $290 \mathrm{~kg}$ (640 lbs) of solid waste each year, including 500 disposable cups and 320 pounds of paper (21). Typically a bulk of the waste volume is generated during the move out of campus at the end of a school year. When the daily student disposal of $0.79 \mathrm{~kg}(1.75 \mathrm{lbs})$ is compared to the average American daily waste disposal of $2.22 \mathrm{~kg}(4.9 \mathrm{lbs})$, the amount is significantly lower. However, when compared to the global average of $0.74 \mathrm{~kg}(1.63 \mathrm{lbs})$, it is higher and presumably getting higher every day (22). 
According to MIT's research, engineering and science laboratories, or medical schools such as "industrialstrength" universities are four times more carbon-intensive per student than the baccalaureate institutions (23). The sustainability laboratory officer at University of Edinburg also indicated that research-laboratories account for two-thirds of the energy bill for the university $(24,25)$. A pilot study by Yale University discovered that divinity schools emitted 100 times less $\mathrm{CO} 2$ than medical schools with technical equipment (26). Similarly, researchers at the University of Exeter weighed up their bioscience department's annual plastic waste and extrapolated that its laboratories generated 267 tonnes of plastic waste due to their daily reliance on cheap, durable, and disposable plastic products (27). This data also indicates that biologically-oriented research institutions worldwide contribute to approximately 5.5 million tonnes of plastic waste which constitutes about $1.8 \%$ of total global plastic production $(24,27)$.

Against this background, an increasing number of HEls from all over the world have pledged to prioritize environmental sustainability by engaging in sustainable practices with concrete and tangible programs on their campuses, and the establishment of several HEls networks at global and regional levels was naturally followed to promote the concept of sustainability in the overall missions and goals of the academic community. Just to name a few, the International Sustainable Campus Network (ISCN), the Climate Leadership Network(CLN), the Association for the Advancement of Sustainability in Higher Education (AASHE), and Green University Network(GUN) are established to share information, ideas and good practices to advance sustainability in HEls. Many HEls put waste management activities as a beginning point for campus sustainability initiatives.

Nevertheless, moving to an environmentally sustainable campus with zero carbon and zero waste is not that simple; it does require new innovative approaches. Using the waste disposal and the associated GHG emissions data from HEl networks, this paper aims to describe how HEls can assume a leadership role in climate mitigation through a carbon pricing initiative, which shifts the burden of the damage from GHG emissions back to those who are responsible for it. After briefly discussing the leading sustainable universities which incorporated carbon pricing as a strategy to acknowledge their important role and their concerns for the environment, this paper estimates the cost of emissions from HEls in order to explain the major benefits of internal carbon pricing in scaling up campus carbon-neutrality initiatives. This paper concludes with practical implications for enhancing sustainable waste management in the university setting.

\section{Opportunities In Higher Education Institutions (Heis)}

Sustainability programs at colleges and universities provide the perfect opportunity to build awareness of the causes, effects, and environmental impacts of our daily actions. College students can and should be the ones who create a call to action against daily habits that are harmful to the environment. For years, HEls played an important role in fostering innovations and driving positive changes in society through the development and integration of sustainable development concepts into learning and operation $(2,28,29)$. More and more HEls pledged to support the UN's sustainable development goals(SDGs) and responsibility redirected their activities so the whole university system is committed to sustainability.

The global survey on Higher Education and Research for Sustainable Development (HESD) identified that 428 universities in 101 distinct countries are actively contributing to the achievement of the SDGs through teaching, research, community engagement, and campus initiatives (30). While not all SDGs are equally addressed by universities, engagement in the SDG 12 (responsible consumption and production) among others has the 
highest potential for continuous development in the HEI context (30). While HEls claim that the lack of the funding is the biggest obstacle for delivering the SDGs (See Figure 2), a cultural shift within the academic community toward upstream options to reduce waste for final disposal and to reuse and recycle valuable resources are perceived to be effective sustainable initiatives to develop their institutional leadership role in promoting sustainable development and helping students, staff and faculty recognize how small changes to their daily practices can make a meaningful difference to society $(31,32)$. After all, what students learn in school can influence the choices they make over the rest of their lives.

\subsection{Carbon Pricing as a Tool for Climate Mitigation}

Since the Kyoto protocol entered into force in 2005, carbon pricing schemes have emerged as a new approach to solving the problem of GHG which assigns a cost to GHG emissions i.e. a price expressed as a value per ton of carbon dioxide equivalent (tCO2e). According to a 2020 World Bank report, there are 61 carbon pricing initiatives in place or scheduled for implementation, consisting of 31 emissions trading systems (ETS) and 30 carbon taxes, covering about 22 percent of global GHG emissions. In 2019, governments around the world raised more than $\$ 45$ billion from carbon pricing (33). While the EU-ETS remains to be the biggest emissions trading market in the world, a growing number of jurisdictions began to implement carbon pricing initiatives, and similarly, in the U.S., the Regional Greenhouse Gas Initiative (RGGI), a collection of Northeastern states with a regional carbon market for the power sector, and California's cap-and-trade program were established in 2005 and 2013 respectively (34). Yet the carbon prices in the U.S. trading markets remain substantially lower than those need to be in line with the goals of the Paris Agreement.

HEls are by no means the best platform to support carbon pricing policies by estimating the campus emissions, setting the right price that will affect people's decisions, charging emitters for their emissions, and ultimately using the money collected through carbon pricing to scale up their climate efforts. HEls are often the size of small municipalities. They require infrastructure and services on the scale of a small municipality and make their own decisions about buildings, and operations and maintenance (35). Placing a monetary value on carbon emissions would build a common language that would help to make campus-wide cohesive financial and operational decisions $(9,36)$. In addition, the purpose of higher education - not bound to maximizing financial profits as is for a typical corporate, will give HEls a luxury to take time to research and test different approaches and come up with solutions that are best fit for their context $(29,37)$.

Having said this, internal carbon pricing may be well-suited in the university setting. While its implementation process may require unique creativity, HEls can contribute to it by creating experiential learning environments toward sustainable practices and educating people to utilize the knowledge in the long-term (37). Despite that the power sector is the dominant sector in carbon trading, emissions trading in other industries such as domestic aviation, transport, buildings, waste, and forestry are also in force (34). Currently, South Korea and New Zealand are the only markets that trade emissions from the waste sector (34). HEls shall place themselves at the forefront of reducing and reusing waste through carbon pricing.

\subsection{Examples of Carbon Pricing Initiatives at HEI}


Inaugurated in 2019, the University Climate Change Coalition (UC3) is a collaborative group of North American Research Universities. Not only have these members pledged to aggressive action plans to reduce carbon footprint, but also have created guidelines and policy platforms to lead cross-sector collaboration. Upon its inauguration, the first topic on the agenda was "the significance of carbon pricing and its implementation at the institution level". In its 2019 report, "the Role of Higher Education in Advancing Carbon Pricing”, they promoted carbon pricing as the most efficient mechanism to decarbonize campus while at the same time incentivizing the campus users to reduce carbon emissions. Internalizing the cost of damages, carbon pricing is complementary to any existing policies unlike carbon credits or carbon offsets which require investments in new or emerging technologies (38)

University of British Columbia is one of the leading universities in North America that have pledged and implemented a number of zero carbon neutral initiatives on campus. UBC has adopted green building standards on campus to ensure all sustainable design and operations opportunities are vetted and the overall operating lifespan of buildings is increased in a cost-effective manner. UBC has also initiated a carbon neutrality action plan which charges a fee of \$25 CAD per tonne of carbon emitted by all university-related air travels (38). The fund generated by carbon pricing was then used to purchase local and community-based offsets equivalent to the emissions associated with those air travels.

Recently, few universities in the U.S. took a similar approach but charged a rather low-end price on carbon. For instance, California State University of East Bay charged a flat fee \$9 USD per round-trip travel with the aim that "all state-funded travel will be carbon neutral or $100 \%$ offset by 2022 "(39). In the case of Arizona State University (ASU), which has been also charging \$8 USD flat fee toward each air travel collected \$169,000 during the 2019 fiscal year. This policy helped offset approximately 45,000 Metric Tons of Carbon Dioxide Equivalents (MTCDE) as well as to plant over 1,000 trees around campus. Yet, ASU has reported that this was rather a policy used in the back-office financial transaction than a university-wide sustainability practice (40).

Yale University was the first university to experiment with the campus-wide internal carbon trading system similar to the EU-ETS and other private sectors. As a pilot, Yale applied a social cost of \$40 per ton of carbon dioxide - estimated by the federal government. This cost is considered to be the social cost at which organizations are paying for the environmental impacts they cause. Using a control group which had no carbon price and a treatment group with a carbon price, the buildings with a carbon price are found to use less energy compared to the baseline emission from the previous academic year. Their research raised people's awareness in energy saving in general, and yet no significant improvement was found in terms of delivering clear messages and motivating students and employees to reduce carbon emissions $(26,41)$. University College London (UCL) took a similar approach but instead incentivized people to reduce energy consumption, with either rebating/charging $£ 30$ tonne (approximately \$40/tonne) based on performance relative to a baseline under the 'Carbon Accountability Scheme' pilot. Rebates are used for energy bills, air travels, or green funds for innovative projects $(26,41)$.

Mostly the collected fees are used to improve infrastructure, increase energy efficiency, and install renewable energy toward carbon neutrality. In a nutshell, it is evident that "carbon pricing" is a dominant carbon-neutrality discourse among many HEls around the globe, yet such a concept has not been expanded to the area of waste management. In other words, carbon pricing in waste management remains an underexplored issue. 


\section{Methodology}

This study is based on several data available online. First, the study used institutions' self-reporting data from the Sustainability Tracking, Assessment, and Rating System (STARS), a rating program administered by the Association for the Advancement of Sustainability in Higher Education(AASHE). Being the only program of its kind that involves publicly reporting information relating to a college or university's sustainability performance, it has rapidly developed since its launch in 2006 with broad participation from the higher education community. The criteria that determine a STARS rating are grouped in five areas: 1) academics 2) engagement, 3 ) operations, 4) planning and administration, and 5) innovation and leadership (42). Based on these criteria, higher institutions receive a STARS rating ranging from bronze, silver, gold, and, platinum. Applying the same criteria to all institutions, the STARS program allows for comparisons among similar institutions, and this is the main reason we chose to use data from the AASHE.

Despite its base in the U.S., AASHE's STARS program is the most widely recognized framework in the world with more than 1,000 institutions from 42 countries in North America, Europe, Asia, and the Middle East participating. To these institutions, the STARS rating is reflective of the breadth and depth of their commitment to being a sustainable learning environment. The STARS ratings and self-reported data the AASHE received through June 2020 were used in this study. The study specifically focuses on data under a section called "Operation 18: Waste Minimization and Diversion" ${ }^{\prime[1]}$ where institutions' estimation of weights of materials disposed in solid waste landfill or incinerator are published.

Among the $430+$ active participants of the AASHE, only those a) located in California and the RGGI ${ }^{[2]}$ states where carbon pricing initiatives are already in place $\left.{ }^{[3]}, b\right)$ being baccalaureate and higher-level institutions with weighted users over 10,000; and c) currently holding a STARS rating higher than Bronze, are analyzed. Thus, the total number of institutions under our selection criteria is 37 from nine states in the U.S. In other words, schools a) located in a region showing strong commitment for climate mitigation, b) with a fairly large number of campus users; and c) already making efforts toward environmental sustainability, are analyzed in order to examine 1) how better they perform in terms of emission reduction in the waste sector compared to other HEls not meeting our selection criteria; and 2) how the implementation of carbon pricing can advance their efforts to achieve environmental sustainability within their campuses.

This study also used the U.S. Environmental Policy Agency (EPA)'s Greenhouse Gases Equivalencies Calculator. In order to perform the calculation, a factor of 2.94 metric tons $\mathrm{CO} 2$ equivalent/ton of waste recycled instead of landfilled from EPA's Waste Reduction Model (WARM) was used $(43,44)$. This factor was developed for recycling rather than landfilling waste following life cycle assessment and the net emission reduction from recycling mixed recyclables $(43,44)$.

Ranging from less than US\$1/tCO2e to US\$906/tCO2e worldwide, the carbon price varies (33). This study used the carbon allowance of $\$ 16.84$ USD which was an average auction CO2 price for the California Cap and Trade program in 2019 (45) as well as an aggressive price of \$40 USD used by Yale University and University College London for their pilot projects $(26,41)$ to calculate the total carbon price per metric tonne. Despite that some organizations purposefully begin with low prices of carbon in order to not drive people away from the idea, yet, international organizations suggest that given the severity of environmental impacts, a rather aggressive value should be used to make significant progress toward carbon neutrality goals (33). 


\section{Results And Analysis}

At the time of the study analysis, 1,018 institutions have registered for AASHE's STARS program. Of these, only 672 are actively reporting their performance in sustainability and hold a STARS rating. Currently, only nine institutions hold a Platinum rating, and of these, five are located either in a RGGI state or California where a carbon trading program is in force. Similarly, out of 133 institutions with a Gold rating, 49 institutions are located either in a RGGI state or California, and the same goes for 46 out of 147 institutions with a Silver rating and 11 out of 47 institutions with a Bronze rating. Overall, 110 out of 330 institutions holding a rating higher than the Bronze rating are located either in a RGGI state or California (Figure 3).

Better performance of these institutions in the RGGI states and California toward climate change and carbon neutrality is evident of how important a state's commitment to climate change is as for giving good inspirations and affecting everyone in it. This also aligns with previous research that California has been the science-based leader in the area of climate change with aggressive decarbonisation targets across public and private sectors $(46,47)$. Put it differently, the poor performance of higher institutions may be an outcome of the low commitment of the state where the institution belongs to. Schmalensee and Stavins (48) emphasized that political considerations have important effects on carbon programs. While the political policy alone would not be sufficient, when combined with a complimentary strategy such as a carbon reduction initiative in a university, the impacts would be larger.

Weighted according to the number of campus users ${ }^{[1]}$, nine institutions out of those 37 selected institutions in this study are found to produce higher amounts of waste per capita than the average amount a college student produces per year (640 lbs) (see Figure 4). Among these nine, four institutions (Stanford University, Univ. of California-Davis, Univ. of California-San Diego, and University of Rochester) are found to be strong outliers producing an average waste of over 1,000 lbs. However, the average amount of materials disposed of in a solid waste landfill or incinerator by all 37 institutions is $556.5 \mathrm{lbs}$ even after these four outliers were taken into account, still being well below the average amount of $640 \mathrm{lbs}$. May not all schools show outstandingly good results, but on average, those who tried to earn even a Bronze rating performed far better than those who did not even try.

According to the self-reports submitted to AASHE, all 37 institutions are found to have moderate to vigorous waste zero, waste reduction, and waste neutrality goals. Accordingly, many of these institutions participate in the annual Campus Race to Zero Waste, formerly Recyclemania, a challenge designed to raise awareness and advance recycling and waste reduction solutions on campus (31). The overarching message of such efforts is to eliminate the linear model where wastes are produced and moved to landfills or incinerators and to promote the reduce, reuse, and recycle (3Rs) principle for a circular economy where waste becomes a resource again for everyday products.

While some types of climate change initiatives have been implemented to protect the environment and keep the campus green by many institutions, none of their initiatives are found to involve financial incentives which have been shown to be effective in changing behavior $(26,41)$. Having said this, this study used internal carbon pricing as a mechanism to evaluate the cost of emitting on to emitters. By putting an explicit price on carbon, 
institutions can not only identify the costs of adding carbon emission to the atmosphere but also identify risks and opportunities and adjust strategy accordingly.

We selected two different monetary values for estimating the costs of carbon emissions: 1 )the average auction price (\$16.84/tCO2e) in 2019 from the California's carbon cap-and-trade program (45), and 2) an internal carbon price $(\$ 40 / \mathrm{tCO} 2 \mathrm{e})$ set by Yale University for its pilot program mentioned earlier in this paper. When these prices are applied in a calculation, the costs incurred by the University of California, Berkeley, one of the lowest emitters among the 37 institutions, range from $\$ 74,371$ to $\$ 436,196$. In the case of the highest emitter among the 37 institutions, Stanford University, the costs it has to bear range from $\$ 140,451$ to as high as $\$ 823,761$ (see Table 1 for all 37 institutions).

In 2012, University of California, Berkeley spent $\$ 71.47$ per tonne to dispose of wastes to landfills, and it would presumably cost higher today (49). When the 2012's fee for waste management services applied, University of California, Berkeley would be spending over $\$ 500 \mathrm{k}$ to dispose of the current amount to landfills, and have a financial burden of $\$ 436,196$ when calculated with a conservative price of $\$ 16.84 / \mathrm{tCO}$ e due to the volume of its emissions. If the more rigorous unit cost of $\$ 40 / \mathrm{tCO} 2 \mathrm{e}$ was taken, the financial burden would exceed the price of the disposal of the waste itself.

In many countries around the globe, the total cost to dispose of solid waste to landfills including collection, transport, treatment, and disposal to landfill ranges from \$45-105 generally exceeding \$100 per tonne (50,51). Beyond this, it is important that institutions take financial responsibility for their emission. By the approach of charging $\mathrm{CO} 2$ emission fees to their internal units (e.g. department), institutions can understand their own carbon footprint and channel the funds generated by this fee back into cleaner technologies and greener activities that support the low-carbon transition.

The combined tonne of $\mathrm{CO} 2$ emissions from the total waste landfilled by all 37 selected institutions is approximately 350,995 tons of CO2e. So, just how much do 350,995 tons mean in everyday terms? When using the U.S. EPA's Greenhouse Gas Equivalencies Calculator $(43,44)$, that's the same as the annual energy use of 40,503 homes and $44,763,172,311$ smartphones charged. It is the same as the annual GHG emissions of 75,830 passenger vehicles. It is also the amount of GHS emissions that could be avoided annually if 14,934,686 trash bags of waste were recycled instead of landfilled.

If all 37 institutions, hypothetically, decide to implement internal carbon pricing at the price of $\$ 40 / \mathrm{tCO} 2 \mathrm{e}$ for the total amount of emissions generated from their campus wastes, this will incur a fee of more than \$14 million in USD. If the institutions decide to use this fee to fund the institutions' emission reduction efforts such as installing solar panels, this fund is large enough to purchase and install more than 930 solar panels around the university campus given the upper bound of the price for the installation of an average-sized solar panel is $\$ 15,000$ (52). These solar panels could bring an annual reduction of 3,570 metric tons of $\mathrm{CO} 2^{[2]}$. This means that in its first year of operation alone, the total $\mathrm{CO} 2$ emissions from their waste would be reduced by $10 \%$ while creating energy large enough to power over 10,000 U.S. homes per year which would worth $\$ 27 m i l l i o n$ in USD ${ }^{[3]}$ $(52,54)$.

If the fee of USD \$14 million were used to plant trees instead to sequester carbon emissions, the fee is large enough to plant about 140,000 mid-size trees (55). Since one tree is known to absorb about 48 lbs of CO2 per 
year, 140,000 trees will sequester approximately $3,000 \mathrm{lbs}$ of carbon annually. The point in fact, the fee created from internal carbon pricing can be a revenue or investment stream to fund the institution's emission reduction efforts. 
Table 1

Cost of CO2 Emissions

\begin{tabular}{|c|c|c|c|c|c|c|c|}
\hline Name of HEI & State & $\begin{array}{l}\text { Materials } \\
\text { disposed } \\
\text { in a solid } \\
\text { waste } \\
\text { landfill or } \\
\text { incinerator }\end{array}$ & $\begin{array}{l}\text { weighted } \\
\text { campus } \\
\text { users* } \\
\text { over } \\
10,000\end{array}$ & $\begin{array}{l}\text { waste } \\
\text { per } \\
\text { CAPITA } \\
\text { (lbs) }\end{array}$ & $\begin{array}{l}\text { metric tons } \\
\mathrm{CO} 2 \\
\text { equivalent }\end{array}$ & $\begin{array}{l}\text { CO2 Price } \\
\text { at } \$ 16.84 \\
\text { USD }\end{array}$ & $\begin{array}{l}\text { C02 Price at } \\
\$ 40 \text { USD }\end{array}$ \\
\hline $\begin{array}{l}\text { University of } \\
\text { Connecticut }\end{array}$ & CT & $2,773.94$ & $22,123.11$ & 529.11 & $8,155.38$ & $\$ 55,620$ & $\$ 326,215$ \\
\hline Yale University & CT & $4,518.60$ & $22,376.63$ & 749.57 & $13,284.68$ & $\$ 90,602$ & $\$ 531,387$ \\
\hline $\begin{array}{l}\text { University of } \\
\text { Delaware }\end{array}$ & $\mathrm{DE}$ & $2,380.32$ & $21,546.75$ & 374.79 & $6,998.14$ & $\$ 47,727$ & $\$ 279,926$ \\
\hline $\begin{array}{l}\text { University of } \\
\text { Maryland, } \\
\text { Baltimore } \\
\text { County }\end{array}$ & $M D$ & $1,109.00$ & $12,929.70$ & 308.65 & $3,260.46$ & $\$ 22,236$ & $\$ 130,418$ \\
\hline $\begin{array}{l}\text { University of } \\
\text { Maryland, } \\
\text { College Park }\end{array}$ & MD & $3,992.90$ & $37,473.58$ & 595.25 & $11,739.13$ & $\$ 80,061$ & $\$ 469,565$ \\
\hline $\begin{array}{l}\text { Boston } \\
\text { University }\end{array}$ & MA & $5,827.00$ & $29,490.75$ & 705.48 & $17,131.38$ & $\$ 116,836$ & $\$ 685,255$ \\
\hline $\begin{array}{l}\text { University of } \\
\text { Massachusetts } \\
\text { Amherst }\end{array}$ & $\mathrm{MA}$ & $3,207.00$ & $27,479.50$ & 595.25 & $9,428.58$ & $\$ 64,303$ & $\$ 377,143$ \\
\hline $\begin{array}{l}\text { University of } \\
\text { New } \\
\text { Hampshire }\end{array}$ & $\mathrm{NH}$ & $1,352.70$ & $14,704.50$ & 352.74 & $3,976.94$ & $\$ 27,123$ & $\$ 159,078$ \\
\hline $\begin{array}{l}\text { Princeton } \\
\text { University }\end{array}$ & NJ & $2,792.00$ & $13,291.50$ & 859.80 & $8,208.48$ & $\$ 55,982$ & $\$ 328,339$ \\
\hline $\begin{array}{l}\text { Binghamton } \\
\text { University }\end{array}$ & NY & $1,694.18$ & $16,323.90$ & 330.69 & $4,980.89$ & $\$ 33,970$ & $\$ 199,236$ \\
\hline $\begin{array}{l}\text { Columbia } \\
\text { University }\end{array}$ & NY & $3,228.94$ & $29,613.75$ & 308.65 & $9,493.08$ & $\$ 64,743$ & $\$ 379,723$ \\
\hline $\begin{array}{l}\text { Cornell } \\
\text { University }\end{array}$ & NY & $3,349.61$ & $27,819.25$ & 661.39 & $9,847.85$ & $\$ 67,162$ & $\$ 393,914$ \\
\hline $\begin{array}{l}\text { New York } \\
\text { University }\end{array}$ & NY & $5,556.40$ & $58,370.50$ & 286.60 & $16,335.82$ & $\$ 111,410$ & $\$ 653,433$ \\
\hline $\begin{array}{l}\text { Rochester } \\
\text { Institute of } \\
\text { Technology }\end{array}$ & NY & $1,692.37$ & $14,644.50$ & 462.97 & $4,975.57$ & $\$ 33,933$ & $\$ 199,023$ \\
\hline $\begin{array}{l}\text { Syracuse } \\
\text { University }\end{array}$ & NY & $3,424.00$ & $18,738.75$ & 749.57 & $10,066.56$ & $\$ 68,654$ & $\$ 402,662$ \\
\hline $\begin{array}{l}\text { University at } \\
\text { Albany }\end{array}$ & NY & $2,034.00$ & $16,046.00$ & 595.25 & $5,979.96$ & $\$ 40,783$ & $\$ 239,198$ \\
\hline
\end{tabular}




\begin{tabular}{|c|c|c|c|c|c|c|c|}
\hline $\begin{array}{l}\text { University at } \\
\text { Buffalo }\end{array}$ & NY & $2,487.69$ & $28,026.50$ & 352.74 & $7,313.81$ & $\$ 49,880$ & $\$ 292,552$ \\
\hline $\begin{array}{l}\text { University of } \\
\text { Rochester }\end{array}$ & NY & $8,611.65$ & $24,657.13$ & 1036.17 & $25,318.25$ & $\$ 172,670$ & $\$ 1,012,730$ \\
\hline $\begin{array}{l}\text { University of } \\
\text { Vermont }\end{array}$ & VT & $1,247.84$ & $13,711.25$ & 396.83 & $3,668.65$ & $\$ 25,020$ & $\$ 146,746$ \\
\hline $\begin{array}{l}\text { California } \\
\text { Polytechnic } \\
\text { State } \\
\text { University }\end{array}$ & $\mathrm{CA}$ & $2,143.00$ & $19,117.00$ & 418.88 & $6,300.42$ & $\$ 42,969$ & $\$ 252,017$ \\
\hline $\begin{array}{l}\text { California } \\
\text { State } \\
\text { Polytechnic } \\
\text { University, } \\
\text { Pomona }\end{array}$ & $\mathrm{CA}$ & $1,766.00$ & $19,437.75$ & 286.60 & $5,192.04$ & $\$ 35,410$ & $\$ 207,682$ \\
\hline $\begin{array}{l}\text { California } \\
\text { State } \\
\text { University, } \\
\text { Chico }\end{array}$ & $\mathrm{CA}$ & $1,146.17$ & $13,995.25$ & 330.69 & $3,369.74$ & $\$ 22,982$ & $\$ 134,790$ \\
\hline $\begin{array}{l}\text { California } \\
\text { State } \\
\text { University, East } \\
\text { Bay }\end{array}$ & $\mathrm{CA}$ & $1,391.69$ & $12,115.50$ & 462.97 & $4,091.57$ & $\$ 27,904$ & $\$ 163,663$ \\
\hline $\begin{array}{l}\text { California } \\
\text { State } \\
\text { University, } \\
\text { Fullerton }\end{array}$ & $\mathrm{CA}$ & $1,162.86$ & $26,163.32$ & 220.46 & $3,418.81$ & $\$ 23,316$ & $\$ 136,752$ \\
\hline $\begin{array}{l}\text { California } \\
\text { State } \\
\text { University, Los } \\
\text { Angeles }\end{array}$ & $\mathrm{CA}$ & $1,070.09$ & $19,504.00$ & 330.69 & $3,146.06$ & $\$ 21,456$ & $\$ 125,843$ \\
\hline $\begin{array}{l}\text { California } \\
\text { State } \\
\text { University, } \\
\text { Northridge }\end{array}$ & $\mathrm{CA}$ & $1,234.28$ & $24,680.00$ & 264.55 & $3,628.78$ & $\$ 24,748$ & $\$ 145,151$ \\
\hline $\begin{array}{l}\text { San Diego } \\
\text { State } \\
\text { University }\end{array}$ & $\mathrm{CA}$ & $1,933.10$ & $26,319.50$ & 242.51 & $5,683.31$ & $\$ 38,760$ & $\$ 227,333$ \\
\hline $\begin{array}{l}\text { San Francisco } \\
\text { State } \\
\text { University }\end{array}$ & $\mathrm{CA}$ & $1,684.70$ & $21,958.28$ & 507.06 & $4,953.02$ & $\$ 33,780$ & $\$ 198,121$ \\
\hline $\begin{array}{l}\text { San Jose State } \\
\text { University }\end{array}$ & $\mathrm{CA}$ & $1,517.00$ & $22,754.50$ & 639.34 & $4,459.98$ & $\$ 30,417$ & $\$ 178,399$ \\
\hline $\begin{array}{l}\text { Stanford } \\
\text { University }\end{array}$ & $\mathrm{CA}$ & $7,004.77$ & $27,507.00$ & 1433.00 & $20,594.02$ & $\$ 140,451$ & $\$ 823,761$ \\
\hline $\begin{array}{l}\text { University of } \\
\text { California, } \\
\text { Berkeley }\end{array}$ & $\mathrm{CA}$ & $3,709.15$ & $45,199.75$ & 396.83 & $10,904.90$ & $\$ 74,371$ & $\$ 436,196$ \\
\hline
\end{tabular}




\begin{tabular}{|c|c|c|c|c|c|c|c|}
\hline $\begin{array}{l}\text { University of } \\
\text { California, } \\
\text { Davis }\end{array}$ & $\mathrm{CA}$ & $6,774.00$ & $37,051.00$ & 1300.73 & $19,915.56$ & $\$ 135,824$ & $\$ 796,622$ \\
\hline $\begin{array}{l}\text { University of } \\
\text { California, } \\
\text { Irvine }\end{array}$ & $\mathrm{CA}$ & $1,467.50$ & $31,523.50$ & 617.29 & $4,314.45$ & $\$ 29,425$ & $\$ 172,578$ \\
\hline $\begin{array}{l}\text { University of } \\
\text { California, Los } \\
\text { Angeles }\end{array}$ & $\mathrm{CA}$ & $8,526.70$ & $63,088.25$ & 683.43 & $25,068.50$ & $\$ 170,967$ & $\$ 1,002,740$ \\
\hline $\begin{array}{l}\text { University of } \\
\text { California, San } \\
\text { Diego }\end{array}$ & $\mathrm{CA}$ & $11,856.00$ & $37,383.75$ & 1102.31 & $34,856.64$ & $\$ 237,722$ & $\$ 1,394,266$ \\
\hline $\begin{array}{l}\text { University of } \\
\text { California, } \\
\text { Santa Barbara }\end{array}$ & $\mathrm{CA}$ & $1,958.00$ & $21,897.75$ & 617.29 & $5,756.52$ & $\$ 39,259$ & $\$ 230,261$ \\
\hline $\begin{array}{l}\text { University of } \\
\text { California, } \\
\text { Santa Cruz }\end{array}$ & $\mathrm{CA}$ & $1,760.90$ & $20,028.50$ & 485.02 & $5,177.05$ & $\$ 35,307$ & $\$ 207,082$ \\
\hline Total & & $119,386.05$ & - & - & $350,994.99$ & $\$ 2,393,786$ & $\$ 14,039,799$ \\
\hline
\end{tabular}

\section{Conclusions}

Internal carbon pricing is a flexible and low-cost approach to reduce carbon emissions at a university-level. It helps reduce emissions and find creative and cost-effective ways to do so without relying on those heavyhanded government regulations or government commitment to any specific national policy.

While there have been a number of bold sustainability initiatives by HEls in recent decades, those were clearly not enough to get students and even the faculty and staff to be environmentally conscious and change their behaviors specifically relating to waste disposal and recycling.

In this study, we tried to examine the effectiveness of carbon pricing in climate mitigation by estimating the cost of emissions from $37 \mathrm{HEls}$ in the US, that have already made a commitment to environmental sustainability by reporting their performance in sustainability to the AASHE on a regular basis. This study found that while many of them have started or currently are preparing some kind of climate action plans for broader aspects of $\mathrm{CO} 2$ reduction, only very few took a strategic approach for emissions associated with campus waste while waste prevention and recycling are real ways to help mitigate climate change. By presenting a couple of carbon-offset investment scenarios using the hypothetical carbon revenues by those $37 \mathrm{HEls}$, this study demonstrates how massive the benefits of carbon pricing could be both in the economic and environmental aspects.

For HEls planning to show strong campus leadership, we recommend first, to internally develop appropriate waste disposal education and color-coded signage which everyone could easily comprehend and provide opportunities for waste management training on proper sorting; and second, in collaboration with recycling and waste disposal contractors, collect and monitor waste disposal data per building and/or colleges. Waste from each college is collected and weighed before being sent for disposal at landfills or incinerators by the waste 
management contractors. It would not be difficult to keep track of the amount of waste and identify which college is more responsible for waste or established incorrect recycling (56). The importance of reliable data production as a means of implementing SDGs is also emphasized in SDGs targets 17.18 and 17.19. In order to monitor various fields of waste management, it is important to develop statistical systems in the area. Third, to set an effective carbon price for internal emissions to achieve the institution' $\mathrm{CO} 2$ reduction goals. This will create incentives for students, faculties, departments, and colleges to choose cleaner options. And funds generated from internal colleges could be further used to invest in sustainable projects to offset $\mathrm{CO} 2$ emissions. Carbon pricing is, of course, not about raising revenues but it would help you recognize that your actions have a cost. In the end, what is most important is participation, collaboration and clear communication among all campus users to reduce emissions around university campuses.

\section{Declarations}

\section{- Ethics approval and consent to participate}

Not Applicable

\section{- Consent for Publication}

Not Applicable

\section{- Availability of data and materials}

All data generated or analysed during this study are included in this published article and its supplementary information files.

\section{- Competing interests}

The authors declare that they have no competing interests

\section{- Funding}

Not Applicable

\section{- Authors contributions}

SuL and SeL equality contributed in writing the manuscript. SeL collected and organized data, calculated the results, conducted literature reviews. SuL analyzed the data, transformed the data into graphic forms, interpreted the data.

\section{- Acknowledgements}

Not Applicable 
1. US EPA O. Overview of Greenhouse Gases [Internet]. US EPA. 2015 [cited 2020 Dec 18]. Available from: https://www.epa.gov/ghgemissions/overview-greenhouse-gases

2. Second Nature. Our History [Internet]. Secondnature.org. [cited 2020 Dec 18]. Available from: https://secondnature.org/our-history/

3. Ritchie H, Roser M. COQ and Greenhouse Gas Emissions. Our World in Data [Internet]. 2017 May 11 [cited 2020 Dec 18]; Available from: https://ourworldindata.org/co2-and-other-greenhouse-gas-emissions

4. US EPA O. National Overview: Facts and Figures on Materials, Wastes and Recycling [Internet]. US EPA. 2017 [cited 2020 Dec 8]. Available from: https://www.epa.gov/facts-and-figures-about-materials-waste-andrecycling/national-overview-facts-and-figures-materials

5. IPCC. AR5 Climate Change 2013: The Physical Science Basis - IPCC [Internet]. 2013 [cited 2021 Jan 3]. Available from: https://www.ipcc.ch/report/ar5/wg1/

6. Maria C, Góis J, Leitão A. Challenges and perspectives of greenhouse gases emissions from municipal solid waste management in Angola. Energy Reports. 2020 Feb 1;6:364-9.

7. US EPA. Inventory of U.S. Greenhouse Gas Emissions and Sinks [Internet]. 2020 p. 30. Available from: https://www.epa.gov/sites/production/files/2020-04/documents/us-ghg-inventory-2020-chapter-executivesummary.pdf

8. Barboza T. Global carbon emissions dropped a record 7\% due to COVID-19. Don't count on it to last. Los Angeles Times [Internet]. 2020 Dec 11 [cited 2020 Dec 31]; Available from: https://www.latimes.com/worldnation/story/2020-12-10/2020-global-carbon-emissions-drop-covid-19

9. Dellink RB, Jamet S, Chateau J, Duval R. Towards global carbon pricing: Direct and indirect linking of carbon markets. OECD. 2014;2013:28.

10. Le Quéré C, Jackson RB, Jones MW, Smith AJP, Abernethy S, Andrew RM, et al. Temporary reduction in daily global CO 2 emissions during the COVID-19 forced confinement. Nature Climate Change. 2020 Jul;10(7):647-53.

11. Konov D. COVID-19 is forcing us to rethink our plastics problem [Internet]. World Economic Forum. 2020 [cited 2020 Dec 18]. Available from: https://www.weforum.org/agenda/2020/05/covid-19-is-forcing-us-torethink-our-plastic-problem/

12. Patrício Silva AL, Prata JC, Walker TR, Duarte AC, Ouyang W, Barcelò D, et al. Increased plastic pollution due to COVID-19 pandemic: Challenges and recommendations. Chemical Engineering Journal. 2021 Feb 1;405:126683.

13. Picheta R. Plastic waste is booming from the coronavirus pandemic - CNN [Internet]. 2020 [cited 2020 Dec 18]. Available from: https://edition.cnn.com/2020/05/04/world/coronavirus-plastic-waste-pollutionintl/index.html

14. Rasmussen G. Those COVID-19 masks, gloves and wipes we're all using are polluting land and sea | CBC News [Internet]. CBC. 2020 [cited 2020 Nov 30]. Available from: https://www.cbc.ca/news/technology/masks-globes-wipes-creating-garbage-1.5600870

15. UNCTAD. Growing plastic pollution in wake of COVID-19: how trade policy can help I UNCTAD [Internet]. 2020 [cited 2020 Dec 18]. Available from: https://unctad.org/news/growing-plastic-pollution-wake-covid-19how-trade-policy-can-help 
16. McGrath M. US top of the garbage pile in global waste crisis. BBC News [Internet]. 2019 Jul 3 [cited 2020 Dec 18]; Available from: https://www.bbc.com/news/science-environment-48838699

17. Turrentine J. The United States Is the Most Wasteful Country In the World [Internet]. NRDC. 2019 [cited 2020 Dec 18]. Available from: https://www.nrdc.org/onearth/united-states-most-wasteful-country-world

18. eurostat. Municipal waste statistics - Statistics Explained [Internet]. 2020 [cited 2021 Jan 5]. Available from: https://ec.europa.eu/eurostat/statistics-explained/index.php/Municipal_waste_statistics

19. EEA. Waste recycling - European Environment Agency [Internet]. [cited 2020 Dec 8]. Available from: https://www.eea.europa.eu/data-and-maps/indicators/waste-recycling-1/assessment-1

20. McCormick E, Fullerton J, Gee A, Simmonds C, Murray B, Fonbuena C, et al. Where does your plastic go? Global investigation reveals America's dirty secret. The Guardian [Internet]. 2019 Jun 17 [cited 2020 Dec 19]; Available from: https://www.theguardian.com/us-news/2019/jun/17/recycled-plastic-america-global-crisis

21. CT DEEP. College and University Recycling [Internet]. CT.gov - Connecticut's Official State Website. 2020 [cited 2021 Jan 5]. Available from: https://portal.ct.gov/DEEP/Reduce-Reuse-Recycle/Schools/College-andUniversity-Recycling

22. Kaza S, Yao LC, Bhada-Tata P, Van Woerden F. What a Waste 2.0: A Global Snapshot of Solid Waste Management to 2050 [Internet]. Washington, DC: World Bank; 2018 [cited 2020 Dec 22]. Available from: http://hdl.handle.net/10986/30317

23. Gutowski T. Can A University Become Carbon Neutral? [Internet]. 2016 [cited 2020 Dec 18]. Available from: http://web.mit.edu/fnl/volume/292/gutowski.html

24. Bell A. Can laboratories curb their addiction to plastic? [Internet]. the Guardian. 2019 [cited 2020 Dec 19]. Available from: http://www.theguardian.com/environment/2019/nov/10/research-labs-plastic-waste

25. Urbina MA, Watts AJR, Reardon EE. Labs should cut plastic waste too. Nature. 2015 Dec;528(7583):479479.

26. Gillingham K, Carattini S, Esty D. Lessons from first campus carbon-pricing scheme: Nature News \& Comment [Internet]. 2017 [cited 2020 Dec 19]. Available from: https://www.nature.com/news/lessons-fromfirst-campus-carbon-pricing-scheme-1.22919

27. University of Exeter. Exeter scientists call for reduction in plastic lab waste [Internet]. 2015 [cited 2020 Dec 14]. Available from: https://www.exeter.ac.uk/news/featurednews/title_488903_en.html

28. Environment UN. Why does education and environment matter? [Internet]. UNEP - UN Environment Programme. 2017 [cited 2020 Dec 4]. Available from: http://www.unenvironment.org/exploretopics/education-environment/why-does-education-and-environment-matter

29. O'Malley B. UN urges universities to be catalysers of sustainability [Internet]. University World News. 2019 [cited 2020 Dec 4]. Available from: https://www.universityworldnews.com/post.php? story $=20190517142734250$

30. Mallow S, Toman I, Land, Hilligje van't. IAU 2nd Global Survey Report on Higher Education and Research for Sustainable Development. UNESCO House: International Association of Universities (IAU); 2020 Jan p. 72.

31. Campus Race to Zero Waste. Why Participate [Internet]. RecycleMania. [cited 2020 Dec 19]. Available from: https://recyclemania.org/participate/why-participate/

32. UNESCO. Partnering for prosperity: education for green and inclusive growth;Global education monitoring report, 2016 [Internet]. 2016 [cited 2020 Dec 19]. Available from: 
https://unesdoc.unesco.org/ark:/48223/pf0000246918

33. World Bank Group. State and Trends of Carbon Pricing 2020 [Internet]. 2020 May p. 109. Available from: https://openknowledge.worldbank.org/bitstream/handle/10986/33809/9781464815867.pdf? sequence $=4 \&$ is Allowed $=y$

34. Santikarn M, Theuer SLH, Eden A, Kellner K, Haug C, Li L, et al. International Carbon Action Partnership (ICAP) Status Report 2019. 2019;12.

35. Barron AR, Parker BJ, Sayre SS, Weber SS, Weisbord DJ. Carbon pricing approaches for climate decisions in U.S. higher education: Proxy carbon prices for deep decarbonization. Elem Sci Anth. 2020 Aug 18;8(1):42.

36. Ahluwalia MB. THE BUSINESS OF PRICING CARBON [Internet]. Center for Climate and Energy Solutions; 2017 Sep p. 40. Available from: https://www.c2es.org/site/assets/uploads/2017/09/business-pricingcarbon.pdf

37. Gonokami M. How universities can become a platform for social change [Internet]. World Economic Forum. 2019 [cited 2020 Dec 19]. Available from: https://www.weforum.org/agenda/2019/06/universitiesplatform-social-change-tokyo/

38. Carter E. The Role of Higher Education in Advancing Carbon Pricing [Internet]. Second Nature; 2019. Available from: https://secondnature.org/wp-content/uploads/SecondNature_UC3_The-Role-Of-Higher-EdIn-Advancing-Carbon-Pricing_Final.pdf

39. Buckholz J. Case Study: University Air-Travel Offset Policy. 2020;3.

40. Dalrymple M. Outcomes from one year of ASU's price on carbon for air travel. 2019;1.

41. Pickett CR, Koste K. Case Study: Carbon Charge. 2016;2.

42. AASHE. STARS, Sustainability Tracking Assessment \& Rating System [Internet]. The Sustainability Tracking, Assessment \& Rating System. 2020 [cited 2020 Dec 15]. Available from: https://stars.aashe.org/

43. US EPA. Greenhouse Gases Equivalencies Calculator - Calculations and References [Internet]. US EPA. 2019 [cited 2020 Dec 15]. Available from: https://www.epa.gov/energy/greenhouse-gases-equivalenciescalculator-calculations-and-references

44. US EPA. Versions of the Waste Reduction Model (WARM) [Internet]. US EPA. 2016 [cited 2020 Dec 20]. Available from: https://www.epa.gov/warm/versions-waste-reduction-model-warm

45. ICAP. USA-California Cap-and-Trade Program [Internet]. 2020. Available from: https://icapcarbonaction.com/en/? option=com_etsmap\&task=export\&format=pdf\&layout=list\&systems\%5B\%5D=45

46. Allison JE, Press D, Horowitz C, Millard-Ball A, Pincetl S. Chapter 7. Paths to Carbon Neutrality: Lessons from California. Collabra [Internet]. 2016 Dec 12 [cited 2020 Dec 17];2(21). Available from: https://doi.org/10.1525/collabra.66

47. Energy Future Initiatives. An Action Plan for Carbon Capture and Storage in California: Opportunities, Challenges, and Solutions [Internet]. 2020 Oct. Available from: https://sccs.stanford.edu/sites/g/files/sbiybj7741/f/efi-stanford-ca-ccs-sfpm-rev1-10.25.20_0.pdf

48. Schmalensee R, Stavins R. Learning from Thirty Years of Cap and Trade [Internet]. Resources for the Future. 2019 [cited 2020 Oct 13]. Available from: https://www.resourcesmag.org/archives/learning-thirty-years-captrade/ 
49. Cockrell C. Trash costs, sustainability pays, says campus recycling 'King' [Internet]. Berkeley News. 2012 [cited 2020 Dec 23]. Available from: https://news.berkeley.edu/2012/02/27/trash-costs-sustainability-payssays-campus-recycling-king/

50. Department of Agriculture, Water and the Environment. The full cost of landfill disposal in Australia [Internet]. Department of Agriculture, Water and the Environment. 2009 [cited 2020 Dec 23]. Available from: http://www.environment.gov.au/

51. Statista. Costs and expenses Waste Management 2019 [Internet]. Statista. 2020 [cited 2020 Dec 23]. Available from: https://www.statista.com/statistics/490794/cost-and-expenses-of-waste-management-inc/

52. Matasci S. How Much Do Solar Panels Cost in 2020? | EnergySage [Internet]. Solar News. 2020 [cited 2020 Dec 31]. Available from: https://news.energysage.com/how-much-does-the-average-solar-panel-installationcost-in-the-u-s/

53. Boston Solar. How Much CO2 Do Solar Panels Save? | Boston Solar | Massachusetts [Internet]. 2020 [cited 2020 Dec 31]. Available from: https://www.bostonsolar.us/solar-blog-resource-center/blog/how-much-co2do-solar-panels-save/

54. US EIA. Electricity use in homes - U.S. Energy Information Administration (EIA) [Internet]. 2019 [cited 2020 Dec 31]. Available from: https://www.eia.gov/energyexplained/use-of-energy/electricity-use-in-homes.php

55. A\&P Nursery. Tree Planting Cost 2019 [Internet]. How much does tree planting cost? 2019 [cited 2020 Dec 31]. Available from: https://www.apnursery.com/tree-planting-costs/

56. Hill K. Understanding the different types of waste management scales [Internet]. Waste Today. 2019 [cited 2021 Jan 3]. Available from: https://www.wastetodaymagazine.com/article/waste-management-scalesweighing-systems/

57. Crunden EA. Landfill operators say cap-and-trade could cost $\$ 138 \mathrm{M}$ in first year alone if emissions standards not changed [Internet]. Waste Dive. 2020 [cited 2020 Dec 23]. Available from: https://www.wastedive.com/news/gwms-republic-waste-management-emissions-nasa-carbonpricing/573065/

\section{Figures}




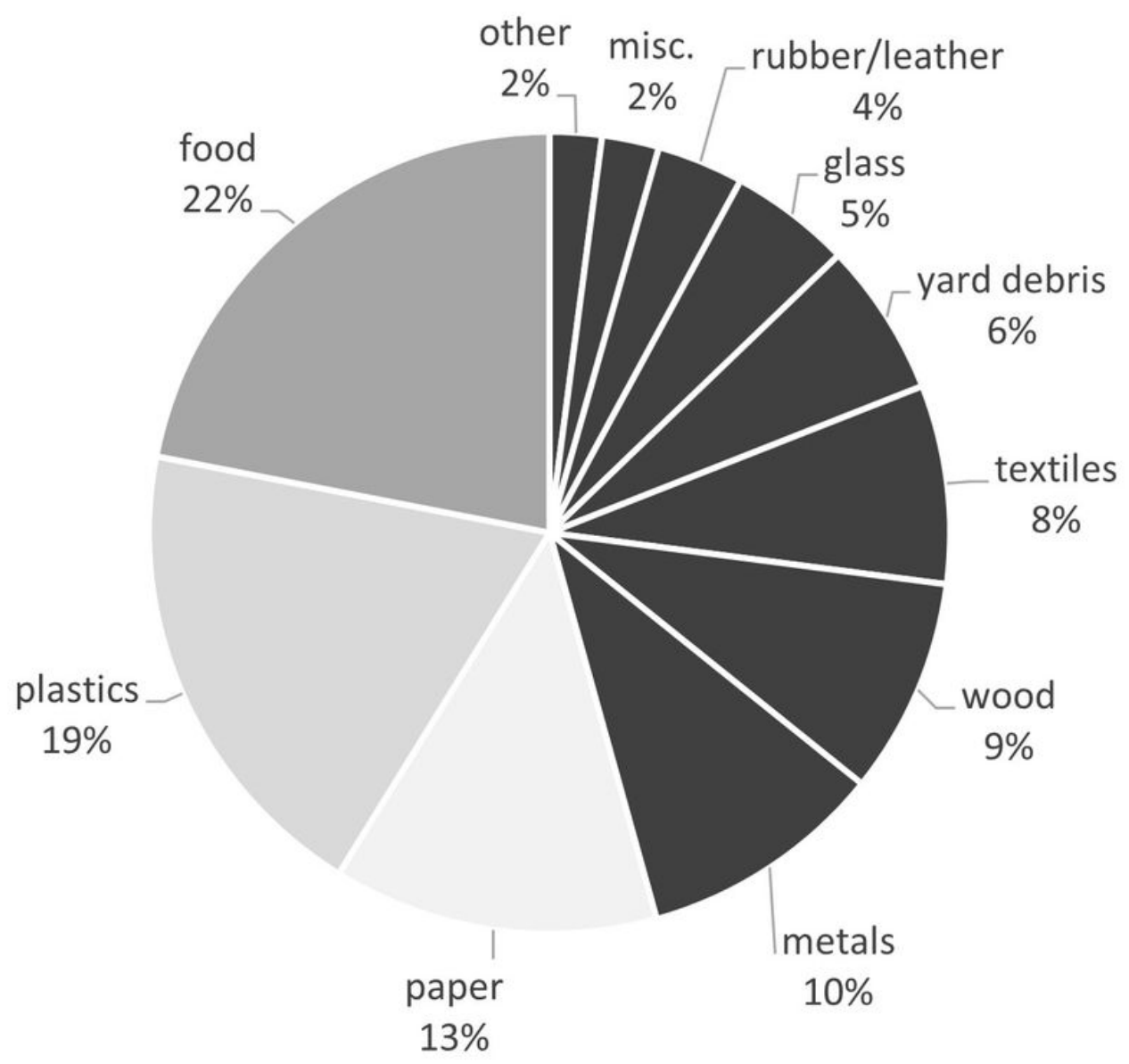

\section{Figure 1}

Breakdown of Landfill Material in the U.S. by Waste Type (unit:\%) Source: graph regenerated using data from the US Environmental Protection Agency (4)

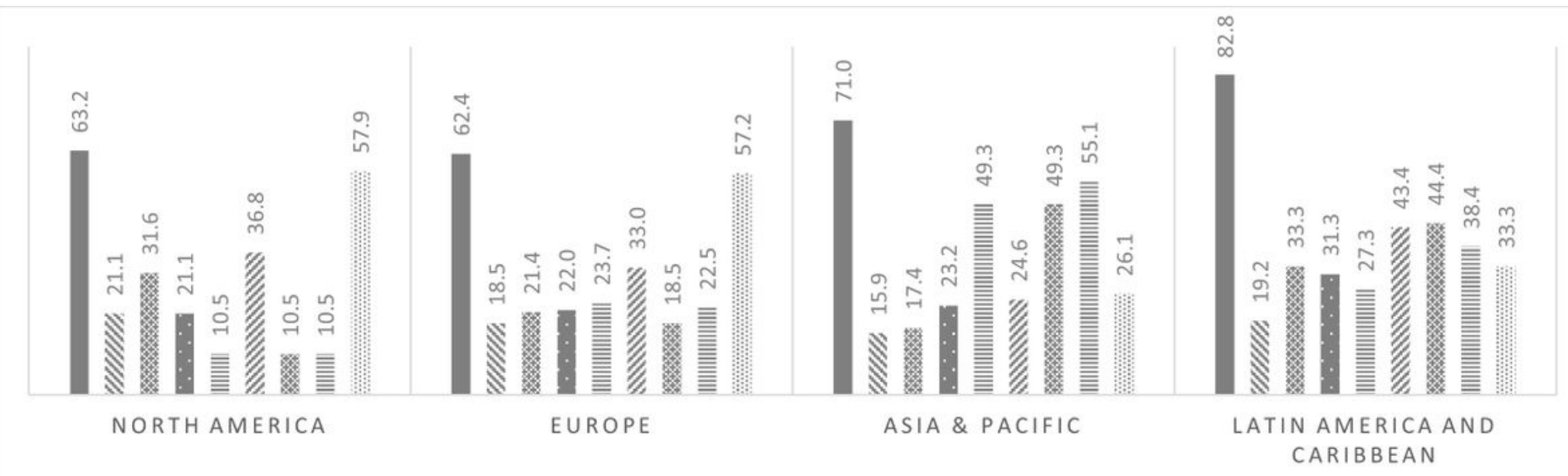

Figure 2 
Difficulties for Sustainable Development Implementation (unit: \%) Source: graph regenerated using data from (30) Note: participants $(n=453)$ of Mallow's study were asked to select all that apply

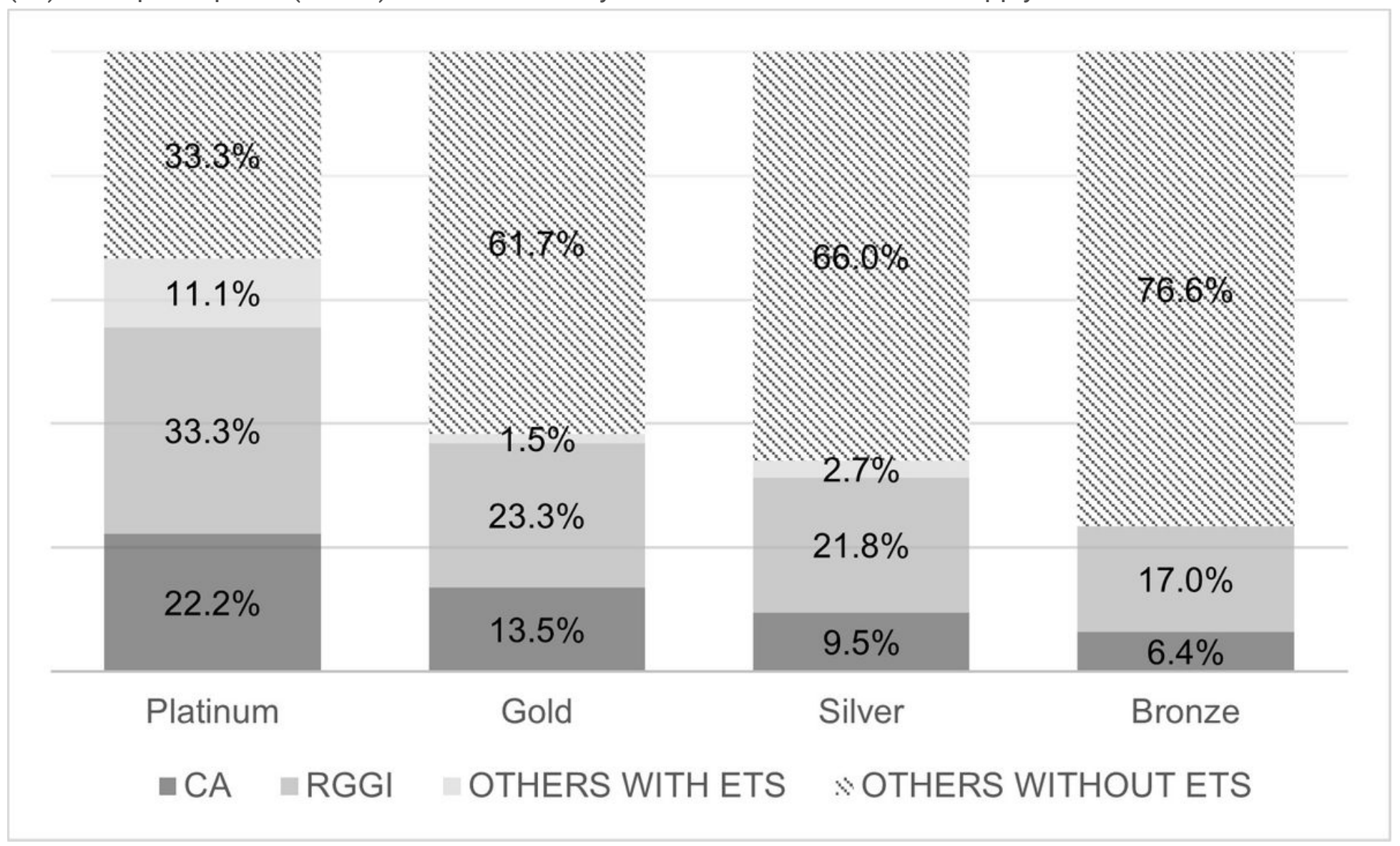

Figure 3

Regional percentage of HEls with a STARS rating Note: "Others with ETS (Emissions Trading System)" consists of HEls from Canada Quebec and Australia participating in the AASHE STARS program 


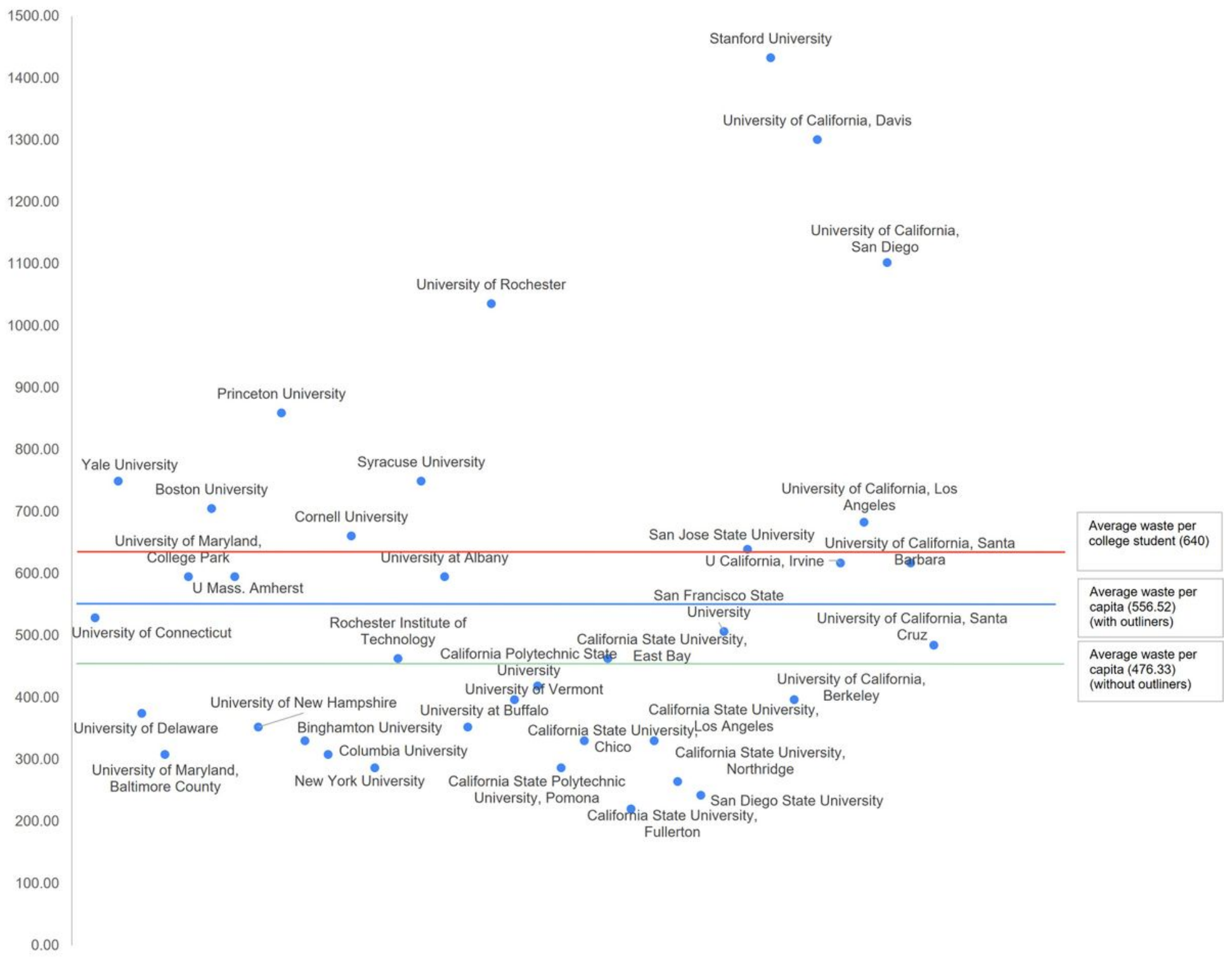

Figure 4

Waste per CAPITA for selected 37 HEls (unit:Ibs) 